\section{Marno Wance}

Magister IImu Pemerintahan Universitas

Muhammadiyah Yogyakarta

Email: arip_guntung @yahoo.com

\section{Suranto}

Dosen Magister Ilmu Pemerintahan

Universitas Muhammadiyah Yogyakarta

Email: suranto_umy@yahoo.com

https://doi.org/10.18196/jgpp.4173

\section{Pola Relasi Eksekutif Dan Legislatif Pada Penyusunan Legislasi Daerah}

(Studi Di Pembahasan APBD Kabupaten Buru

Selatan 2015)

\begin{abstract}
This study is shown to measure the impact of the rising of many South Buru district budget is problematic (mistimed), namely from the year 2010 to 2015 discussions always happen tug of interests that result in a delay of APBD. therefore be important to do a study on (1), the Executive and Legislative Relationship Patterns in South Buru budget discussion. (2) Factors relations executive and legislative In the discussion of the budget. based on the findings of this study concluded that the first, found three patterns of interaction (accommodation, domination, compromise), but between the three patterns of interaction of the budget policy discussion found any more process dominate. Second, the interaction patterns decisional is a pattern of disagreement that took place in the formulation (KUA) and (PPAS) resulting keterlamabatan determination of the budget, the interaction patterns of power that occurred bargaining (barganing) to exchange the interest of the legislature to the executive are not accommodated On (RKA) SKPD These three, namely the interaction patterns Anticipated Reaction South Buru District Government receives the benefit of parliament who form the recess recommendation to maintain the stability of the Year 2015.Keempat discussion of budget, non-decisional interaction pattern that the legislature refuses to KUA and PPAS discussion because of the executive did not submit documents Plans Work Budget (RKA) from each SKPD. While facto factors influencing ang Relationship Patterns executive and legislative discussion of budget 2015 ie Personal Bachground, political Bachground

Keywords - the executive-legislative relations, local legislation
\end{abstract}

\begin{abstract}
ABSTRAK
Penelitian ini ditunjukan untuk mengukur dampak dari banyak terbitnya APBD Kabupaten Buru Selatan yang bermasalah (tidak tepat waktu) yaitu dari tahun pembahasan 2010 sampai 2015 selalu terjadi tarik ulur kepentingan yang mengakibatkan keterlambatan penetapan APBD. oleh karenanya menjadi penting untuk dilakukan studi tentang (1), Pola Relasi Eksekutif dan Legislatif pada Pembahasan APBD Buru Selatan. (2), Faktor-faktor relasi eksekutif dan Legislatif Pada Pembahasan APBD. berdasarkan temuan penelitian dapat disimpulkan bahwa pertama, ditemukan tiga pola interaksi (akomodasi, dominasi, kompromi) namun di antara ketiga pola interaksi dari pada pembahasan kebijakan anggaran ditemukan adanya proses yang lebih mendominasi. Kedua, pola interaksi decisional yaitu pola pertentangan yang berlangsung pada perumusan (KUA) dan (PPAS) sehingga mengakibatkan keterlamabatan penetapan APBD, pola interaksi kekuasaan yang terjadi tawar menawar (barganing) untuk melakukan pertukaran kepentingan legislatif kepada Eksekutif yang tidak diakomodir Pada (RKA) SKPD.Ketiga, pola interaksi Anticipated Reaction yaitu Pemerintah Kabupaten Buru Selatan menerima kepentingan DPRD yang mejadi rekomendasi Reses untuk menjaga kestabilan pembahasan APBD Tahun 2015.Keempat, Pola interaksi Non Decisional yaitu pihak legislatif menolak melakukan pembahasan KUA dan PPAS karena dari pihak eksekutif tidak menyerahkan dokumen Rencana Kerja Anggaran (RKA) dari masing-masing SKPD. Sedangkan Fakto-faktor ang mempengaruhi Pola Relasi eksekutif dan legislatif pada pembahasan APBD Tahun 2015 yaitu Personal Bachground, political Bachground Kata Kunci — Relasi eksekutif-legislatif, legislasi daerah
\end{abstract}




\section{PENDAHULUAN}

Anggaran pendapatan belanja daerah merupakan proses anggaran di sektor publik sudah sepantasnya menjadi prioritas dan menjadi perhatian bagi pemerintah daerah. Keterlambatan dalam penetapan APBD apabila terus terjadi akan menjadi patologi-patologi legislasi yang akan terus secara berlanjut maka akan berimplikasi pada terhambatnya pembangunan daerah. Sehingga pemerintah daerah serta DPRD berupaya untuk mengatasi pengaruh keterlambatan pada pembahasan pada tingakat Rencana Kerja Anggaran (RKA) akan mempengaruhi ketermlabatan pada penetapan dan pengesahan legislasi daerah. Keterlambatan dalam penyusunan APBD akan dapat mengakibatkan lambannya penetapan anggaran untuk di undangkan menjadi peraturan daerah (Perda). Akibat keterlambatan ini ialah berupa sangsi penundaan penyaluran dana perimbangan bahkan hingga potongan anggaran.

Tabel I. Penetapan APBD Kabupaten Buru Selatan

\begin{tabular}{|l|l|l|l|}
\hline Perda APBD & Diundangkan & Ditetapkan & Batas Waktu \\
\hline Nomor 01 Tahun 2010 & $12 / 11 / 2010$ & $12 / 11 / 2010$ & $31 / 12 / 2012$ \\
\hline Nomor 01 Tahun 2011 & $24 / 11 / 2012$ & $24 / 11 / 2012$ & $08 / 01 / 2011$ \\
\hline Nomor 01 Tahun 2012 & $24 / 11 / 2012$ & $24 / 11 / 2012$ & $31 / 12 / 2012$ \\
\hline Nomor 01 Tahun 2013 & $25 / 01 / 2013$ & $25 / 11 / 2013$ & $31 / 12 / 2013$ \\
\hline Nomor 01 Tahun 2014 & $18 / 01 / 2014$ & $18 / 01 / 2014$ & $31 / 01 / 2014$ \\
\hline Nomor 01 Tahun 2015 & $20 / 01 / 2015$ & $20 / 01 / 2015$ & $31 / 01 / 2015$ \\
\hline
\end{tabular}

Sumber: Perda APBD Kabupaten Buru Selatan

Anggaran Pendapatan Belanja Daerah (APBD) mempunyai peran yang sangat penting dalam menyusun prioritas perencanaan 
110 pembangunan daerah. Maka akibat keterlambatan dalam penetapan APBD Buru Selatan pada Enam tahun terakhir akan sangat berdampak pada pelaksanaan program dan kegiatan pembangunan daerah menjadi tidak efektif dan efisien. Sehingga faktor keterlambatan penetapan anggaran karena kurangnya komitmen dan kompeten tentang proses pembahasan APBD. ataukah faktor lain yang dapat di analisis yaitu faktor komunikasi dan koordinasi antara eksekutif- legislatif yang kurang mampu membangunan mitra kerja yang harmonis karena kurangnya ruang-ruang publik baik secara formal maupun informal.

Sejak Kabupaten Buru Selatan diimplementasikan menjadi daerah otonomi baru pada tahun 2008 pola hubungan eksekutif dan legislatif telah terjadi berulang-ulang proses keterlambatan Penetapan Anggaran Pendapatan Belanja Daerah (APBD). Banyaknya fenomena keterlambatan/tidak aspiratif tersebut dikarenakan proses pembahasannya yang elitis.sifat elitisme ini ditunjukan dengan adanya perilaku aktor-aktor yang terlimbat dalam pembahasan APBD Buru Selatan tahun 2015 yaitu Pemerintah Daerah (eksekutif) dan DPRD (Legislatif) yang sangat lamban dalam menetapkan anggaran daerah untuk di undangkan menjadi Peraturan Daerah (Perda). Karena dengan adanya Peraturan Daerah (Perda) Buru Selatan menjadi acuan dan dasar hukum tetap Pemerintah daerah dalam menjalankan program-program pembangunan untuk pagu anggaran satu tahun.

Keterlambatan penetapan karena pola hubungan elit lokal yaitu antara legislatif dan eksekutif masih berbeda persepsi yaitu: Menurut ketua DPRD Buru Selatan Arkilaus Solissa menegaskan pembahasan 
APBD tahun anggran 2015 tidak ada penetapan jika pemerintah daerah (pemda) belum menyerahkan dokumen Rencana Kerja anggran (RKA) yang harusnya diserahkan oleh pemerintah kabupaten buru selatan kepada Dewan Perwakilan Rakyat Daerah (DPRD) untuk dibahas secara bersama-sama. Sebab Rencana Kerja Anggaran (RKA) menjadi acuan sekaligus prinsip dalam pembahasan Anggaran Pendapatan Belanja Daerah (APBD). Landasannya tertuang di Permendagri No 21 Tahun 2011 tentang pedoman pengelolaan keuangan daerah pasal 106 ayat 1 yaitu "Apabila DPRD sampai batas waktu sebagaimana dimaksud dalam Pasal 105 ayat (3C) tidak menetapkan persetujuan bersama dengan kepala daerah terhadap rancangan peraturan daerah tentang APBD, kepala daerah melaksanakan pengeluaran setinggi-tingginya sebesar angka APBD tahun anggaran sebelumnya". Senada dengan apa yang disampaikan oleh anggota DPRD Buru Selatan dari Fraksi PAN yaitu Thaib Souwakil bahwa hingga kini dewan belum menerima dokumen Rencana Kerja Anggaran (RKA) untuk di bahas di tingkat badan anggaran karena menurutnya DPRD tidak mau membahas perencaaan Angggaran Pendapatan Belanja Daerah (APBD) tanpa dokumendokumen sebagai standar Operasional tidak ada RKA yang menjadi objek pembahasan APBD tahun 2015.

Interaksi aktor politik daerah sudah kelihatan dari pembahasan APBD Tahap III selalu di warnai pengaruh dari fraksi dan komisi di DPRD Kabupaten Buru Selatan. Sehingga berdampak pada pola interaksi antara pemerintah daerah dan DPRD, dalam kaitannya dengan Badan Anggaran (Banggar) DPRD Buru Selatan ketika 
112 melakukan pembahasan APBD Tahun 2015. Kekuatan politik yang di miliki oleh tiap fraksi tidak mampu mengimbangi wewenang pemerintah daerah sehingga interaksi yang terjadi ketika membahasan rancangan APBD tidak seimbang. Aspek lain yang harus di tinjau pada pembahasan APBD Buru Selatan tahun 2015 yaitu, Peratma, perbedaan persepsi antara pemerintah daerah dan DPRD tentang wewenang masing-masing ketika membahas rancangan APBD dan perbedaan persepsi internal DPRD yang mengarah pada pengotak internal dalam DPRD Buru Selatan. Kedua, keterbatasan kapasitas Sumber Daya Manusia (SDM) dan kelembagaan DPRD dalam memahami proses dan materi penganggaran daerah serta kontravensi DPRD. Ketiga, perbedaan persepsi antara pemerintah daerah dengan DPRD Buru Selatan ini dalam perkembangannya dapat menjadi kontravensi (pertentangan tertutup) yang di landasi oleh sikap ketidakpercayaan.

\section{METODE PENELITIAN}

Jenis penelitian ini menggunakan pendekatan deskriptif kualitatif yaitu menurut bogdan da Taylor (dalam Moeleng: 2011:4) metode kualitatif sebagai prosedur penelitian yang menghasilkan data deskriptif berupa kata-kata tertulis atau lisan dari orang-orang dan perilaku yang dapat di amati.

\section{Unit Analisis Data}

Unit analisis data pada penelitian ini adalah Pemerintah Kabupaten Buru Selatan, SKPD dan DPRD. 
Table II Unit Analisis Data

\begin{tabular}{|c|c|}
\hline $\begin{array}{l}\text { Institusi (Pemerintah Kabupaten } \\
\text { dan DPRD Buru Selatan ) }\end{array}$ & $\begin{array}{l}\text { Jumlah } \\
\text { Responden }\end{array}$ \\
\hline Ketua DPRD Buru Selatan & 1 Orang \\
\hline $\begin{array}{l}\text { Sekda Buru Selatan atau Tim } \\
\text { Anggaran Pemerintah Daerah } \\
\text { (TAPD) }\end{array}$ & 1 Orang \\
\hline $\begin{array}{l}\text { Badan Anggaran DPRD Buru } \\
\text { Selatan }\end{array}$ & 1 Orang \\
\hline $\begin{array}{l}\text { Ketua-ketua Fraksi DPRD Buru } \\
\text { Selatan }\end{array}$ & 5 Orang \\
\hline Jumlah & 8 Orang \\
\hline
\end{tabular}

\section{Jenis Data}

\section{Data Primer}

Sumber data primer yang digunakan dalam penelitian ini adalah sumber data yang di peroleh secara langsung dengan metode wawancara dari responden atau objek penelitian yang sesuai dengan permsalahan yang terjadi di lapangan. Adapun sumber data primer yaitu sebagai berikut:

\section{Table III Data Primer}

\begin{tabular}{|c|c|c|}
\hline Sumber data & $\begin{array}{l}\text { Teknik } \\
\text { pengumpulan data }\end{array}$ & Dokumen yang di butuhkan \\
\hline $\begin{array}{l}\text { Ketua DPRD Buru } \\
\text { Selatan }\end{array}$ & Wawancara & $\begin{array}{l}\text {-Dokumen KUA dan PPAS } \\
\text {-Nota Kesepakatan KUA dan PPAS }\end{array}$ \\
\hline $\begin{array}{lr}\text { Tim } & \text { Anggaran } \\
\text { Pemerintah } & \text { Daerah } \\
\text { (TAPD) } & \\
\end{array}$ & Wawancara & $\begin{array}{l}\text {-Dokuemen RPJMN dan RKPD } \\
\text {-Dokumen RKA-SKPD }\end{array}$ \\
\hline $\begin{array}{l}\text { Badan Anggaran } \\
\text { DPRD }\end{array}$ & Wawancara & $\begin{array}{l}\text { Dokuemen Penyusunan KUA- } \\
\text { PPAS }\end{array}$ \\
\hline Ketua-ketua Fraksi & Wawancara & $\begin{array}{l}\text {-Dokumen Pandangan KUA-PPAS } \\
\text {-Dokumen Pandangan Raperda } \\
\text { APBD }\end{array}$ \\
\hline
\end{tabular}




\section{Teknik Analisis Data}

Pada penelitian ini ada tiga metode analisis data yang menjadi acuan dalam penulisan berdasarkan pada pendapat Hubermas dalam Mukhtar (2013: 135) bahwa analisis data deskripti kualitatif mencakup reduksi data, penyajian data, dan penarikan kesimpulan. Sehingga analisis data adalah mengelompokan, membuat sesuai urutan, memanipulasi serta menyingkat data sehinggah mudah untuk di baca. Hal ini berkaitan dengan dengan pengujian secara sistematis terhadap sesuatu untuk menentukan bagian dan hubungan antar bagian .

\section{HASIL DAN PEMBAHASAN}

1. Interaksi Pemerintah Daerah dan DPRD Pada Proses Pembahasan KUA-PPAS

a. Tahapan Penyusunan KUA-PPAS

Proses penyusunan KUA-PPAS Kabupaten Buru Selatan Tahun 2015 pada Pembahasan RAPBD merupakan Pengelolaan Keuangan daerah yang di atur oleh Permendagri Nomor 13 Tahun 2006 tentang pedoman pengelolaan keuangan daerah. Sehingga yang menjadi syarat untuk merumuskan KUA-PPAS dengan melakukan penjaringan aspirasi masyarakat yang menjadi acuannya yaitu dokumen Perencanaan Daerah, Rencana Kerja Pemerintah Daerah (RKPD) serta perencanaan nasional maupun kebijakan pemerintah pusat yang berlaku. Penjaringan Aspirasi yang dilakukan oleh DPRD Kabupaten Buru Selatan dilakukan dalam upaya untuk menampung segala kebutuhan-kebutuhan masyarakat di Daerah Pemilihan masing-masing. 
Maka untuk menganalisis Pola Relasi Eksekutif dan Legislatif pada pembahasan APBD Kabupaten Buru Selatan Tahun 2015 maka Tahapan Kebijakan Umum Anggaran (KUA) dan Prioritas dan Platfon Anggaran Sementara (PPAS) akan ditemukan bentuk-bentuk pententangan yang selalu berdampak negatif dan selalu bertolak belakang dengan dengan pola-pola hubungan antara eksekutif maupun legislatif secara kelembagaan. Bentukbentuk pertentangan yang muncul dalam penyelenggaraan pemerintah adalah pola pertentanagn politik yang melibatkan berbagai macam kelompok kepentingan untuk menjadikan Prioritas Anggaran sebagai objek kepentingan kelempok tertentu. Oleh karenanya dalam menganalisis pola relasi yang terjadi di Kabupaten Buru Selatan digunakan beberapa pendekatan yaitu Sebagai berikut:

1) Pola Relasi Decesional Asosiatif

Pola Relasi Decesional dalam bentuk Asosiatif merupakan bentuk interaksi kepentingan antara Pemerintah Kabupaten dengan DPRD yang dirumuskan Pada tahapan RKA-PPAS APBD. pola interaksi antara kelembagaan dapat dilakukan dalam bentuk tawar menawar kepentingan yang dapat berlangsung melalui bentuk akomondasi misalnya bentuk Coercion di mana Pemerintah Kabupaten terpaksa mengakomondasi kepentingan DPRD dengan maksud untuk mengurangi tekanan secara kelembagaan Legislatif dalam proses formulasi kebijakan Anggaran. Pola pertentangan yang berlangsung pada saat perumusan misalnya DPRD cenderung selalu melakukan penundaan jadwal persidangan untuk memperlambat proses perumusan anggaran, lembaga legilatif selalu menggalang pola kekuatan untuk melibatkan pihak-pihak eksternal dalam 
116 mempengaruhi Opini Publik bahwa cenderung DPRD Selalu mementingkan kepentingan konstituen.

Berdasarkan pada hasil wawancara pada penelitian menunjukan bahwa pola pertentangan yang terjadi pada saat perumusan APBD Kabupaten Buru Selatan Tahun Anggaran 2015, DPRD selalu menggunakan Kekuatan kewenangan dalam mempengaruhi Keputusan Politik yang akan di putuskan. Menurut Salah satu Pimpinan DPRD Kabupaten Buru Selatan

"Pada pembahasan APBD Kabupaten Buru Selatan Tahun Anggaran 2015 yang di awali oleh penyerahan Kebijakan Umum Anggaran (KUA) serta Prioritas dan Platfom Anggaran Sementara (PPAS) yang secara langsung di serahkan oleh Pemerintah Kabupaten Diwakili oleh Wakil Bupati Buce Ayub Saleky. Namun pada penyerahan yang dialakukan oleh Pemerintah Kabupaten Sudah melewati Jadwal yang ditentukan yaitu padahal yang sebenarnya pada tanggal 20 bulan juni sudah masuk pembahasan RKA-PPAS di DPRD ". (Wawancara kamis 21 Agustus 2015 Pukul 11:32 WIT).

Permasalahan yang terjadi di Kabupaten Buru Selatan Pada pembahasan APBD Kabupaten Buru Selatan Tahun 2015 yaitu pada saat proses penjaringan aspirasi masyarakat yang dilakukan model penjaringan dari Musyawarah Pembangunan mulai dari tingkat Desa, Kecamatan hingga ke Kabupaten. Dari mekanisme ini, baik Pemerintah Kabupaten Buru Selatan dan DPRD harus berusaha semaksimal mungkin mengangkat isu-isu kebijakan publik yang menjadi kebutuhan masyarakat. Proses Penjaringan yang dilakukan oleh DPRD akan menjadi landasan yang mendasar dalam melakukan perumusan KUA-PPAS secara bersama-sama dengan hasil-hasil penjaringan yang dilakukan oleh Pemerintah Kabupaten Buru Selatan. 
Pada tahap perumusan penganggaran, terdiri dari proses penyusunan Kebijakan Umum Anggaran (KUA) Serta Prioritas dan Platfom Anggaran Sementara (PPAS) bahwa proses penyusunan Rancangan Anggaran Pendapatan Belanja Daerah (RAPBD), dan proses penetapan APBD Tahun 2015 di Kabupaten Buru Selatan. Berdasarkan pada Permendagri Nomor 13 Tahun 2006 menyatakan penandatangan nota kesepakatan atas rancangan KUA-PPAS antara kepala daerah dengan DPRD dilakukan paling lambat akhir bulan Juli. Namun yang terjadi adalah penandatangan nota kesepakatan tersebut tidak sesuai dengan ketentuan, kecuali TA 2013, sebagaimana tabel 3 berikut ini :

Table IV Nota Kesepakatan KUA-PPAS Kabupaten Buru Sel
\begin{tabular}{|l|l|l|l|}
\hline No & Tahun & Tanggal Disepakati & Batas Waktu \\
\hline 1 & 2010 & 23 Novemer 2010 & 31 Juli 2010 \\
\hline 2 & 2011 & 20 Juli 2011 & 31 juli 2011 \\
\hline 3 & 2012 & 28 Agustus 2012 & 31 Juli 2012 \\
\hline 4 & 2013 & 18 November 2013 & 31 Juli 2013 \\
\hline 4 & 2014 & 24 Dese,ber 2014 & 31 Juli 2014 \\
\hline
\end{tabular}

Sumber: Bappeda dan Litbang Buru Selatan, 2015

Berdasarkan pada uraian nota kesepakatan KUA-PPAS maka ada beberapa Permasalahan yang menjadi penyebab keterlambatan dalam penandatanganan nota kesepakatan tersebut sudah terjadi sejak proses penyusunan rancangan KUA-PPAS di eksekutif. Hal tersebut dapat dilihat dari penyampaian rancangan KUA-PPAS kepada DPRD yang sering terlambat sebagai contoh rancangan KUA-PPA Tahun 2010 
118 disampaikan kepada DPRD pada tanggal 31 Juli 2009 dengan Surat Bupati Nomor: 809/519 Tahun 2010. Sedangkan untuk rancangan KUA-PPAS Tahun 2014 baru disampaikan kepada DPRD pada tanggal 2 Desember 2014 dengan Surat Bupati Nomor: 903/524 Tahun 2014. (Risalah Sidang DPRD Buru Selatan, 2015).

Setelah rancangan KUA-PPAS selesai disusun eksekutif, selanjutnya disampaikan ke DPRD. Pada saat proses pembahasan rancangan KUA-PPAS di rapat Banggar DPRD sering mengalami kendala molornya waktu pembahasan akibat menunggu quorum dari anggota Banggar DPRD. Kurangnya komitmen kehadiran legislatif dalam pembahasan rancangan KUA-PPAS menjadi penyebabnya. Selain itu ketidakjelasan hubungan antara program kegiatan dalam PPAS dalam mendukung kebijakan anggaran di KUA menjadikan pembahasan yang memakan waktu. Hal tersebut diakibatkan rancangan KUA-PPAS yang disusun eksekutif tidak terhubung secara substansi.

\section{2) Pola Anticipated Reaction Asosiatif}

Pola relasi pada model yaitu bentuk interaksi yang terjadi dalam bentuk kooptasi, di mana pemerintah daerah menerima kewenangan DPRD untuk menjaga kestabilan pemerintahan daerah. Bentukbentuk interaksi juga terdapat dalam bentuk interaksi akomondasi yaitu bentuk coercion atau atas dasar keterpaksaan pemerintah daerah untuk menolak atau menerima kepentingan-kepentingan elit legislator. Interaksi aktor dalam melakukan perumusan Anggaran Pendapatan Belanja Daerah (APBD) Kabupaten Buru Selatan Tahun Anggaran 2015 masih di dominasi pemerintah daerah sebagai aktor yang melakukan tahapan perumusan sampai pengajuan untuk di Bahas di 
tingkat paripurna DPRD. Interaksi dalam mempengaruhi APBD tahun 2015 dilakukan pemerintah kabupaten dalam bentuk-bentuk akomondasi kepentingan maupun kooptasi sehingga memunculkan masalah pertentngan dalam interaksi antara institusi eksekutif dan legislatif untuk menciptakan APBD yang komprehensif dan partisipatif. Sementara pergeseran peran yang sangat prinsip dari masyarakat kepada DPRD pada tahap penyusunan dan pembahasan anggaran tidak berjalan efektif. DPRD justru terjebak dalam masalah prosedural dengan lebih mengutamakan kepentingan diri sendiri karena DPRD lemah dalam menjalankan fungsinya.

Pada tahap ini keputusan didominasi oleh pemerintah daerah (agent) yang disebut tipe interaksi Anticipated Reaction. Bentuk interaksi yang dilakukan oleh DPRD dalam mengakomondir kepentingan Masyarakat khususnya masyarakat miskin (principal) memiliki posisi lemah karena terdiskriminasi sehingga proses ini kurang memprioritaskan usulan yang di ajukan oleh DPRD Kabupaten Buru Selatan. Tindakan tersebut ditimbulkan oleh masalah interaksi kepentingan individu yaitu adanya perilaku pemerintah daerah dan DPRD untuk mementingkan diri sendiri, terdapat informasi asimetris antar Pemerintah Daerah dan DPRD, serta adanya monopoli informasi maupun data oleh Masyarakat yang dilakukan melalui ruang-ruang publik yaitu forum Musrembang Desa tidak bisa di akomondir pada saat Pembahasan APBD Tahun 2015.

Maka untuk menganalisis bentuk interaksi Anticipated Reaction Asosiatif pada pembahasan APBD Kabupaten Buru Selatan Tahun 2015. Berdasarkan pada hasil wawancara oleh Kepala Bappeda yaitu 
121 Bapak Sahrul Pawa bahwa Langkah-langkah pemerintah daerah untuk menerima kewenangan DPRD dalam menjaga kestabilan Pemrintah Kabupaten Buru Selatan, Menurutnya bahwa:

"Bahwa tahapan penyusunan program pada forum musrembang Desa di undang pemangku kepentingan yaitu pemerintah desa, tokoh agama, tokoh adat, tokoh pemuda dan masyarakat. Dari hasil pembahasan Musrembang desa di tetapkan minimal 5 program dari kesepakat Qourom untuk di tetapkan dan langsung di berita acarakan untuk ditindaklanjuti serta disesuaikan pada program apa saja yang menjadi skala prioritas pada satu tahun kedepan, kemudian dimasukan pada usula Rencana Kerja (Renja) SKPD Kabupaten Buru Selatan”.(Hasil Wawancara Selasa 09 Agustus 2015, Pukul 12:23 Wit)

Berdasarkan pada tahap ini pemerintah daerah paling kuat mempengaruhi politik anggaran yang disebut tipe interaksi Anticipated Reaction. Pemerintah daerah sebagai Agen untuk menyusun Kerangka Konseptual APBD telah memperlemah kekuatan DPRD sebagai principal dalam melakukan pembahasan pada Tingkat KUA-PPAS yang sudah memuat program masing-masing SKPD pada tahun anggaran berikutnya. Ruang gerak DPRD untuk melakukan pencermatan terbatas pada pembahasan KUA dan PPAS dan tidak dilibatkan dalam penyusunan RKA SKPD. Oleh karena itu mudahnya kepentingan pemerintah daerah terakomodir termasuk menurunan skala prioritas pada penyusunan RKA SKPD Tahun anggaran APBD 2015. Hal ini berdampak pada program yang diusulkan tidak berpihak masyarakat miskin dari tahapan Musrenbang Desa mengalami pemangkasan signifikan di PPAS. Tindakan pemerintah daerah tersebut telah melanggar kontrak dikarenakan masalah 
keagenan seperti perilaku lebih mementingkan diri sendiri, adanya rasionalitas terbatas dan adanya upaya menghindari resiko, adanya informasi asimetris antara principal dan agent, serta adanya monopoli informasi maupun data oleh agent.

\begin{tabular}{|c|c|c|c|}
\hline Tahun & $\begin{array}{ll}\text { Surat } & \text { Ke } \\
\text { DPRD } & \end{array}$ & Tanggal Pengiriman & Batas waktu \\
\hline 2010 & $\begin{array}{l}889 / 520 \text { Tahun } \\
2010\end{array}$ & 26 November 2010 & 7 September 2010 \\
\hline 2011 & $\begin{array}{l}\text { 900/521 Tahun } \\
2011\end{array}$ & 10 Agustus 2011 & 7 September 2011 \\
\hline 2012 & $\begin{array}{l}\text { 901/522 Tahun } \\
2012\end{array}$ & 27 November 2012 & 7 September 2012 \\
\hline 2013 & $\begin{array}{l}\text { 902/523 Tahun } \\
2013\end{array}$ & 27 November 2012 & 7 September 2013 \\
\hline 2014 & $\begin{array}{l}\text { 903/524 Tahun } \\
2014\end{array}$ & 29 Desember 2014 & 7 Septemb \\
\hline
\end{tabular}

\section{Sumber: Bappeda dan Litbang Buru Selatan, 2015}

Berdasarkan pada tabel di atas, keterlambatan penyampaian RAPBD kepada DPRD sebagian besar akibat keterlambatan dalam penandatangan nota kesepakatan KUA-PPAS, namun saratnya kepentingan eksekutif dalam penyusunan RAPBD juga menjadi penyebab yang pada akhirnya dibutuhkan waktu yang lama dalam penyusunannya. Hal tersebut sangat terlihat pada penyusunan RAPBD untuk Tahun 2010 yang membutuhkan waktu hampir 3 bulan 25 hari, dan pada Tahun 2015 yang membutuhkan waktu hampir 4 bulan 21 hari, padahal batas waktu sesuai Permendagri 13 Tahun 2006 hanya 8 minggu. Hal tersebut membuktikan bahwa eksekutif kurang memiliki komitmen dalam mentaati jadwal penyusunan APBD, sehingga menyebabkan penyampaian RAPBD kepada DPRD mengalami keterlambatan. RAPBD yang telah disusun 
122 selajutnya disampaikan ke DPRD untuk dilakukan pembahasan. Proses pembahasan di DPRD melalui rapat Badan Anggaran serta Komisi. Pada rapat Komisi, pembahasan semua program kegiatan menggunakan RKA-SKPD. Pembahasan dilakukan per digit belanja kegiatan. Hal tersebut tentu saja memakan waktu dalam pembahasan meskipun hal tersebut baik untuk melihat detil anggaran. (Risalah Sidang DPRD Buru Selatan, 2015).

3) Pola Interaksi Non Decesional Asosiatif

Pola interaksi model Nondecesional Making merupakan bentuk pertemuan antara institusi Eksekutif dan Legislatif untuk menggunakan kekuasaan wewenangnya ataupun sumber daya yang dimiliki dalam rangka untuk mempengaruhi pengambilan keputusan, baik menyangkut substansial maupun konteks APBD Kabupaten Tahun Anggaran 2015. Selain itu, bentuk pola interaksi yang digunakan antara lain penyebaran Isu publik, isu kelompok kepentingan untuk mendukung atau menentang proses penyusunan Anggaran.

Sedangkan untuk menganalisis pandangan Pemerintah Kabupaten dan DPRD menyangkut substansi dan konteks APBD Kabupaten Buru Selatan maka berdasarkan hasil wawancara dengan Bapak Sami Latbual bahwa menurtnya:

"Pada penyusunan APBD Kabupaten Buru Selatan Tahun 2015 dari tahapan pembahasan Program kerja di masing-masing Satuan Kerja Perangkat Daerah (SKPD) sudah di persoalkan terkait dengan substansi pembahasan anggaran, karena pada saat proses penyerahan KUA-PPAS dari Tim TPAD tidak menyerahkan Draf rangcangan dari masingm-masing SKPD. 
Sehingga dari pihak legislatif tetap menolak untuk melakukan pembahasan APBD pada tahapan berikutnya, karena memang SKPD harus menyerahkan draf program yang akan menjadi landasan untuk menyusun APBD Tahun 2015".(Hasil Wawancara Jumat 19 Agustus, Pukul 10:43 Wit ).

Berdasarkan pada hasil wawancara tersebut bahwa pembahasan APBD tahun 2015 terjadi pertentangan kepentingan antara aktor Eksekutif dan Legislatif daerah dalam memandang tentang substansi orentasi anggaran yang akan diputuskan pada rapat paripurna dilakukan oleh legislatif daerah. Pola Perilaku Aktor politik yang terjadi pada hasil kajian yang dilakukan adalah bahwa pembahasan Rancangan Anggaran Pendapatan Belanja Daerah (APBD) sudah tidak berjalan sesuai dengan mekanisme yang diterapkan, mulai dari pembahasan KUA, pada pembahasan PPAS, paripurna tentang penjelasan Bupati terhadap RAPBD dan Nota keuangan, paripurna tentang pandangan fraksi terhadap Nota Keuangan, pembahasan RKA-SKPD di ringkat panitia Anggaran, pembahasan tingkat komisi, penyerasian anggaran ditingkat panitia ditingkat panitia anggaran, paripurna untuk penetapan perda anggaran.

Alasan utama dimana Aktor kebijakan, terutama dari sisi pemerintah daerah mengusulkan anggaran pendapatan yang akan dilaksanakan untuk tahun 2015 adalah bahwa usulan anggaran pendapatan dan belanja yang diusulkan selalu meminta pendapat dan tanggapan mulai dari bawah hingga didiskusikan pada tahap pematangan program dan proyek lewat RAPBD. Bila diperhatikan apa yang terjadi pada saat pengamatan dilakukan seperti diutarakan diatas adalah dapat dijelaskan bahwa proses perumusan kebijakan RAPBD 
124 ternyata dilakukan sesuai dengan mekanisme yang telah ditetapkan sebelumnya.

Dari sisi lain perdebatan antara Aktor tidak dapat dihindarkan tatkala para Aktor kebijakan masih mempersoalkan besaran anggaran yang diusulkan oleh terutama pihak eksekutif. Kenyataan ini didukung oleh berbagai hasil pengamatan penulis yang menunjukkan bahwa sesungguhnya perdapatan antar kelompok aktor tidak bias dihindari terutama pada pembahasan ditingkat panitia anggaran yang melibatkan SKPD untuk menyampaikan RKA-nya, walaupun yang mendominasi jalannya siding adalah anggota Dewan. Dalam hal ini berarti bahwa dominasi aktor lain terhadap aktor tertentu masih tetap ada dalam proses RAPBD Kabupaten Buru Selatan Tahun 2015.

Table VI Interaksi Pemerintah Kabupaten dan DPRD Tahun Anggaran APBD 2015

\begin{tabular}{|c|c|c|}
\hline $\begin{array}{l}\text { Bentuk } \\
\text { Interaksi }\end{array}$ & Perumusan KUA-PPAS & Pembahasan APBD \\
\hline $\begin{array}{l}\text { Akomond } \\
\text { asi }\end{array}$ & $\begin{array}{l}\text { Pada perumusan KUA-PPAS, } \\
\text { DPRD cencerung akomondasi- } \\
\text { partisipatif dalam melakukan } \\
\text { pembahasan } \\
\text { dilaksanakan. Hal tersebut } \\
\text { berkaitan dengan kewwenangan } \\
\text { eksekutif. }\end{array}$ & $\begin{array}{l}\text { Proses akomondatif } \\
\text { DPRD terhadap pihak } \\
\text { eksekutif } \quad \text { (SKPD) pada } \\
\text { realitasnya terjadi pada saat } \\
\text { proses pembahasan anggaran } \\
\text { di tingkat komisi. }\end{array}$ \\
\hline Dominasi & $\begin{array}{l}\text { Eksekutif secara umum } \\
\text { mendominasi proses perumusan } \\
\text { KUA-PPAS sebagai konsekuensi } \\
\text { dari aspek pihak Pemerintah } \\
\text { Kabupaten dalam mengajukan } \\
\text { untuk di bahas di institusi legislatif }\end{array}$ & $\begin{array}{lr}\text { Kecenderungan } & \text { DPRD } \\
\text { mendominasi } & \text { proses } \\
\text { pembahasan } & \text { RAPBD baik } \\
\text { pada sisi kemasyarakatan } \\
\text { maupun pada alokasi sumber } \\
\text { keuangan daerah. pola } \\
\text { interaksi ini pada akhirnya } \\
\text { menimbulkan }\end{array}$ \\
\hline
\end{tabular}




\begin{tabular}{|c|c|c|}
\hline & & kepentingan. \\
\hline $\begin{array}{l}\text { Kompromi } \\
\text { stik }\end{array}$ & $\begin{array}{l}\text { Pola interaksi antara Pemerintah } \\
\text { Kabupaten dan DPRD pada } \\
\text { tahapan pembahasaan KUA- } \\
\text { PPAS tidak terjadi secara } \\
\text { kompromi tetapi lebih diperankan } \\
\text { oleh eksekutif }\end{array}$ & $\begin{array}{l}\text { Pola aktor DPRD cenderung } \\
\text { kompromistik apabila SKPD } \\
\text { yang di bahas merupakan } \\
\text { kordinasi antara sektor. Maka } \\
\text { SKPD cenderung lebih lambat } \\
\text { dan tidak komprmistik. }\end{array}$ \\
\hline
\end{tabular}

\section{Sumber: Hasil Analisis Lapangan}

Sehinggga dari beberapa penjelasan atas dari hasil di lapangan, maka dapat dianalisis ketimpangan yang terjadi dalam interaksi pemerintah Kabupaten dan DPRD dalam perumusan KUA-PPAS Kabupaten Buru Selatan Tahun Anggaran 2015. Maka dari itu dengan menggunakan pendekatan kekuasaan dan ketergantungan power and resources depedenci dalam perspektif kekuasaan dan sumber daya yang lebih memiliki oleh pemrintahan daerah pada pembahasan APBD Kabupaten Buru Selatan untuk mempengaruh sikap kebijakan DPRD di lihat sangat lemah dari sisi kekuasaan atau sumber daya.

Konteks kekuasaan bukan hanya terbatas pada wewenangan politik secara normative saja, namun bisa terkait dengan sumber daya manusia (SDM) yang dimiliki oleh DPRD, baik kemampuan DPRD untuk menjaring aspirasi masyarakat dan aktor yang melakukan pembahasan APBD maupun kemampuan untuk menggali data/informasi serta permsalahan rakyat secara komprhensif 
2. Faktor-faktor pola relasi eksekutif dan legislatif pada pembahasan APBD

1. Faktor Interest (Kepentingan)

Faktor-faktor pola interaksi pada pembahasan anggaran mengalami polarisasi kepentingan antara kelompok-kelompok yang mendominasi dan didominasi sehingga terjadi pasang surut karena terjadi keterlambatan penyusunan Anggaran Pendapatan Belanja Daerah (APBD) Kabupaten Buru Selatan Tahun 2015 telah berdampak pada sebagian besar wilayah Kecamatan sekitarna dan hal itu apabila telah berlangsung pada kurun waktu yang lama bahkan hingga saat ini. Kabupaten Buru Selatan merupakan salah satu daerah yang tergolong mengalami keterlambatan dalam menyusun APBD dari tahun 20102015. Anggaran Pendapatan Belanja Daerah (APBD) pada kelima tahun anggaran tersebut disahkan pada kurun waktu antara 1 Januari - 31 Maret. Selain banyaknya daerah yang mengalami keterlambatan dalam penetapan APBD, adanya keterlambatan APBD dapat memberikan dampak negatif. Dampak yang ditimbulkan dari keterlambatan dalam penyusunan APBD adalah terlambatnya pelaksanaan program pemerintah daerah yang umumnya sebagian besar pendanaan program tersebut berasal dari APBD. Program yang terlambat dilaksanakan dapat berpengaruh pada pelayanan publik terhadap masyarakat.

Fenomena kepentingan para elit lokal pada pembahasan APBD Kabupaten Buru Selatan Tahun Anggaran 2015 sangatlah kompleks. Maka peneliti mencoba mewancarai ketua Fraksi Partai Demokrasi Indonesia Perjuangan (PDI-P) Sami Latbual menurut bahwa: 
"Dalam setiap perencanaan pembangunan daerah sudah tentu baik dari pemerintah Kabupaten Buru Selatan maupun DPRD mempunyai kepentingan politik. Yang menjadi persoalan mendasar kenapa banyak kepentingan dari legislatif sering kali tidak di akomodir di postur APBD. Pada dua institusi tersebut mempunyai dasar yang kuat, kami mempunyai data masalah apaapa saja yang di butuhkan masyarakat desa karena kami dalam tiga tiga bulan malakukan reses di desa daerah pemilihan (Dapil). Sedangkan pihak eksekutif punya sarana forum musrembang yang selama ini dilaksanakan oleh Pemkab Buru Selatan baru sebatas formalitas semata, belum efektif untuk menyerap aspirasi dan usulan-usulan dari masyarakat yang banyak dari $R T-R W$ sampai tingkat daerah persentase jumlahnya semakin berkurang". (Hasil Wawancara Jumat 19 Agustus, Pukul 10:43 Wit.)

Maka berdasarkan pada hasil wawancara tersebut di atas bahwa yang menjadi persoalan terjadi pertentangan kepentingan antara legislatif maupun eksekutif pada setiap pembahasan anggaran, karena forum-forum reses yang dilakukan oleh legislatif di pangkas pada tingkat Rencana Kerja Anggaran (RKA) SKPD Buru Selatan. Semestinya, hasil musrembang (eksekutif) maupun reses (pihak legislatif) sebagai sarana penyerapan aspirasi masyarakat. Yang menjadi kendala dalam setiap forum ini masyarakat belum aktif secara mental dalam menyampaikan usulan basis kebutuhan mendasar bukan keinginan karena sebagian besar masyarakat yang diikut sertakan belum mampu merumuskan kebutuhannya. Selain itu, pola relasi pemerintah daerah (eksekutif dan legislatif) dan masyarakat belum begitu efektif untuk penyerapan aspirasi masyarakat dan partisipasi masyarakat hanya berpartisipasi hanya mengusulkan tapi tidak semua usulan terakomondasi dalam dokumen RKPD dan APBD, karena 
128 yang menjadi alasan keterbatasan anggaran maka sangat perlu untuk adanya mana program yang menjadi prioritas usulan.

Table VII Usulan Aspirasi di Musrembang Se-Kecamatan Buru Selatan

\begin{tabular}{|l|c|c|c|c|c|c|c|}
\hline \multicolumn{1}{|c|}{ Program } & $\begin{array}{c}\text { Kec. } \\
\text { NM }\end{array}$ & $\begin{array}{c}\text { Kec. } \\
\text { LK }\end{array}$ & $\begin{array}{c}\text { Kec. } \\
\text { WS }\end{array}$ & $\begin{array}{c}\text { Kec. } \\
\text { KM }\end{array}$ & $\begin{array}{c}\text { Kec } \\
\text { AB }\end{array}$ & $\begin{array}{c}\text { Kec. } \\
\text { FF }\end{array}$ & Jmh \\
\hline $\begin{array}{l}\text { Pembangunan } \\
\text { Gedung }\end{array}$ & 2 & 4 & 3 & 4 & 3 & 4 & 20 \\
\hline $\begin{array}{l}\text { Pembangunan } \\
\text { Talud/Broncong }\end{array}$ & 4 & 3 & 4 & 4 & 4 & 4 & 23 \\
\hline $\begin{array}{l}\text { Pembangunan } \\
\text { Jalan }\end{array}$ & 3 & 3 & 4 & 2 & 0 & 3 & 23 \\
\hline $\begin{array}{l}\text { Pembangunan } \\
\text { Jembatan }\end{array}$ & 4 & 3 & 2 & 4 & 4 & 0 & 15 \\
\hline $\begin{array}{l}\text { Rehabilitasi } \\
\text { Jembatan }\end{array}$ & 3 & 2 & 3 & 0 & 0 & 4 & 13 \\
\hline $\begin{array}{l}\text { Pengembangan air } \\
\text { dan limbah }\end{array}$ & 4 & 3 & 2 & 3 & 3 & 3 & 18 \\
\hline $\begin{array}{l}\text { Pengadaan Perahu } \\
\text { piber }\end{array}$ & 4 & 5 & 4 & 4 & 5 & 0 & 22 \\
\hline $\begin{array}{l}\text { Peningkatan } \\
\text { pelayanan } \\
\text { angkutan }\end{array}$ & 3 & 3 & 2 & 4 & 0 & 4 & 16 \\
\hline $\begin{array}{l}\text { Pembangunan } \\
\text { drainase }\end{array}$ & 4 & 2 & 4 & 3 & 2 & 4 & 19 \\
\hline $\begin{array}{l}\text { Pembangunan } \\
\text { telekomunikasi }\end{array}$ & 2 & 3 & 3 & 4 & 2 & 4 & 18 \\
\hline Jumlah & 36 & 35 & 36 & 44 & 30 & 30 & 14 \\
\hline Keterangan & & & & & \\
\hline
\end{tabular}

Keterangan:

Kec. NM : Kecamatan Namrole; Kec LK : Kecamatan Leksula

Kec. WS : Kecamatan Waesama; Kec. KM : Kecamatan Kepala Madan

Kec. FF : Kecamatan Fena Fafan;

Sumber: Bappeda Buru Selatan 2015 (data diolah)

Pada tabel di atas bahwa memuat beberapa usulan dari masyarakat untuk di akomodir dalam APBD Tahun 2015 yaitu 164 usulan yang terdiri 11 usulan. Namun di bandingkan dengan usulan pada tahun 
2014 naik menjadi 164 usulan masyarakat, kecamatan Kapala Madan persentase usulan lebih besar yaitu 44 usulan, di ikuti Kecamatan Waesama 36 usulan, Kecamatan Leksula 35 usulan, Kecamatan Namrole 36 Usulan, Kecamatan Ambalau 30 Usulan dan Kecamatan Fena Fafan 30 usulan. Berdasarkan pada uraian tersebut di atas dapat disimpulkan bahwa usulan dari masyarakat di musrembang tiap tahun berubah baik jumlah maupun kelompok usulannya. Usulan tahun 2014 berjumlah 175 sedangkan usulan tahun 2015 menurun tajam menjadi 164. Sehingga dari beberapa usulan aspirasi masyarakat pada forum musrembang akan di bahas dan disetujui bersama pihak eksekutif oleh Tim Anggaran Pemerintah Daerah (TPAD )dan legislatif oleh Badan Anggaran (Banggar) dengan melakukan analisis dan persamaan persepsi untuk mengakomodir aspirasi-aspirasi pembangunan berdasarkan pada usulan masyarakat agar masuk dalam APBD.

Tim Anggaran Pemerintah Daerah (TAPD) menurut Permendagri 13 Tahun 2006 tentang pengelolaan keuangan daerah merupakan tim yang di bentuk oleh Pemerintah Kabupaten Buru Selatan dengan keputusan kepala daerah dan dipimpin oleh sekretaris daerah yang mempunyai tugas menyiapkan serta melaksanakan kebijakan daerah dalam rangka melakukan penyusunan APBD yang beranggotakan terdiri dari Pejabat perencanaan daerah dan PPKD (Pejabat Pengelolaan Keuangan Daerah) dan disesuaikan dengan kebutuhan dengan tujuan di bentuk TPAD untuk menyusun dokumen perencanaan daerah untuk satu tahun anggaran. Sebelum pembahasan APBD oleh TAPD dan Banggar, disusun kebijkan 


\section{1 umum Anggaran (KUA) dan Prioritas dan Plafon Anggaran} Sementara (PPAS) yaitu rancangan program prioritas anggaran sebagai acuan untuk penyusunan APBD sebelum disepakati secara bersama dengan DPRD. Berikut ini wawancara dengan bapak Sahrul Pawa selaku Kepala Bappeda Kabupaten Buru Selatan sebagai berikut:

"Proses pembahasan musrembang Desa yang di undang menjadi peserta dari unsur pemerintah Desa, tokoh masyarakat, tokoh Agama, tokoh pemuda yang berjumlah 12 orang, hasil dari diskusi di forum Musrembang Desa yaitu program yang masuk di berita acara minimal 5 (lima) program untuk di jadikan acua untuk skala prioritas pada usulan Renja SKPD. Yang menjadi kendala ketika pada saat pembahasan Musrembang Kabupaten yang terdiri dari TPAD dan DPRD untuk melakukan evaluasi hasil-hasil penyusunan RKPD, rekomendasi Musrembang Desa maupun masukan dari pihak DPRD berdasarkan pada rekomendasi reses yang sudah di lakukan dan menjadi bahasan permasalahan di daerah. namun yang menjadi persoalan, kenapa banyak kepentingan Legislatif tidak di akomodir karena Musrembang Kabupaten sudah di undang secara resmi namun Institusi DPRD tidak hadir padahal hasil musrembang Kabupaten sangat stategis karena menjadi acuan bagi masing-masing SKPD untuk menyusun Rencana Kerja Anggaran (RKA) ”. (Hasil Wawancara Selasa 09 Agustus 2015, Pukul 12:23 Wit).

Sedangkan Menurut wawancara dengan Ketua Fraksi KPS Bapak Masrudin Solissa mengungkapkan bahwa pada penyusunan APBD Kabupaten Buru Selatan banyak aspirasi rakyat tidak pernah di akomodir, adapun kutipan hasil wawancara sebagai berikut:

"Proses penjaringan aspirasi baik yang dilakukan oleh Pemerintah Kabupaten Melalui Musrembang maupun forum reses yang dilakukan oleh legislatif (DPRD) tidak pernah menemukan titik temu kepentingan pada proses pembahasan APBD. namun saya menilai bahwa pembahasan APBD hanya dijadikan ajang traksaksional/traksaksi berbagai macam kepentingan politik, apalagi 
pembahasan APBD tahun 2015 yang sudah mendekati perhelatan Pilkada serentak. Sehingga penyusunan anggaran tidak sebanding dengan hasil yang di dapat masyarakat. Di sisi lain bahwa antara eksekutif dan legislatif mempunyai tugas dan tanggung jawab yang sama pada penjaringan aspirasi rakyat namun banyak sekali kepentingan DPRD dalam memperjuangan kebutuhan dasar masyatakat tidak pernah di akomodir."

Berdasarkan pada uraian hasil wawancara dia atas bahwa pola interkasi kepentingan antara eksekutif dan legislatif pada pembahasan anggaran sangat sarat dengan kepentingan politik maupun ekonomi. Sehingga mengakibatkan pada penggunaan kekuatan kewenangan yang di miliki untuk mempengaruh keputusan politik anggaran yang akan diputuskan. Berakibat pada berbagai macam aspirasi selain dari masyarakat, hasil-hasil reses DPRD dengan melakukan kunjungan lapangan ke konstituen pada masing-masing daerah pemilihan yang bertujuan untuk menyerap aspirasi masyarakat. Aspirasi melalui forum reses legislatif sebagai bentuk kebutuhan masyarakat yang di salurkan melalui wakil rakyat yang akan di sampaikan dan di tuangkan di berbagai program dan kegiatan yang akan diusulakan pada pembahasan APBD tahun 2015.

Pola Penyerapan aspirasi terbagi menjadi dua bentuk yaitu pola penyerapan aspirasi masyarakat oleh pihak Eksekutif (Pemda) dan pola penyerapan aspirasi masarakat oleh legislatif (DPRD). Pola interaksi aspirasi yang dilakukan oleh Eksekutif dan Legislatif melalui proses perencanaan pembangunan dilakukan secara langsung maupun tidak langsung. Proses agregasi aspirasi masyarakat yang dilakukan oleh DPRD secara langsung dengan dialog tatap muka, kunjungan lapangan saat kerja di masa sidang atau masa Reses. Tujuannya untuk 
132 bisa meyerap aspirasi, menghimpun dan menampung aspirasi masyarakat untuk di perjuangkan pada saat pembahasan APBD. sedangkan secara tidak langsung berupa konsultasi anggota legislatif dengan eksekutif setempat untuk menjadi catatan penting bagi SKPD dalam menyusun Renja Kebijakan Umum Anggaran (KUA). Hasilhasil Reses DPRD merupakann kunjungan lapangan ke konstituen pada masing-masing daerah pemilihan dengan maksud untuk menyerap segala kebutuhan mendasar yang di butuhkan baik progrman maupun kebutuhan pemberdayaan masyarakat untuk di usulkan dalam pembahasan APBD.

\section{Faktor Capacity (Kemampuan)}

Fungsi anggaran terhadap pemnahasan APBD Kabupaten Buru Selatan Tahun 2015 faktanya masih sangat lemah. Faktor-faktor yang sangat berpengaruh keterlambatan penetapan anggaran yaitu Personal background, Political background dan pemahaman anngota DPRD tentang pengelolaan anggaran, hal ini disebabkan karena latar belakang individu dalam aktivitas politik.

\section{a) Personal Background}

Berdasakan pada hasil analisis data tentang tingkat pendidikan anggota DPRD Kabupaten Buru Selatan masih sangat minim karena masih di dominasi para legislatif yang pengalaman pendidikan belum pernah mengenyam pendidikan. Maka untuk dapat memenuhi akan tenaga kerja yang bermutu dan mampu melaksanakan program pendidikan. Pelaksanaan pendidikan di harapkan mampu kepada peningkatan ketrampilan, pengetahuan serta sikap atau perilaku 
pemahaman kerja yang rasional, elegan, berwibawa dan diharapkan adanya perubahan sikap dan perilaku negatif menjadi positif dalam menghasilakan produk legislasi di bidang anggaran.

Table VIII Komposisi Anggota DPRD Buru Selatan Menerut Tingkat Pendidikan

\begin{tabular}{|l|l|l|l|l|l|}
\hline \multirow{2}{*}{ Fraksi } & \multicolumn{4}{|l|}{ Tingkat Pendidikan } & \multirow{2}{*}{ Jumlah } \\
\cline { 2 - 6 } & SLTA & Akademi & S1 & S2 & \\
\hline$(1)$ & $(2)$ & $(3)$ & $(4)$ & $(5)$ & $(6)$ \\
\hline PDI-P & 3 & 0 & 1 & 0 & 4 \\
\hline Partai Demokrat & 1 & 0 & 1 & 1 & 3 \\
\hline Partai Gerindra & 2 & 0 & 1 & 0 & 3 \\
\hline PAN & 1 & 0 & 2 & 0 & 3 \\
\hline Perubahan* & 0 & 0 & 3 & 1 & 4 \\
\hline KPS $^{*}$ & 1 & 0 & 2 & 0 & 3 \\
\hline Jumlah & 8 & 0 & 10 & 2 & 20 \\
\hline
\end{tabular}

Sumber: Sekretariat DPRD Buru Selatan, 2015

Keterangan:

Fraksi Perubahan : Nasdem, PKB, Hanura. Fraksi KPS : PPP, Golkar, PKS

Sehingga bahwa latar belakang pendidikan berpengaruh negatif terhadap keterlambatan penyusunan anggaran. Artinya, semakin baik kemampuan dan bidang ilmu yang dikuasai oleh seseorang selama menempuh jalur pendidikan, maka terjadinya keterlambatan dalam penyusunan APBD akan dapat dihindari. Latar belakang pendidikan ini meliputi meliputi latar belakang pendidikan formal dan informal. Dilihat dari latar belakang pendidikan formal diketahui bahwa masih minimnya anggota DPRD yang memiliki latar belakang pendidikan yang terkait dengan penyusunan anggaran. Disamping itu masih minimnya pendidikan dan pelatihan terkait pengganggaran keuangan 
134 daerah yang diikuti oleh tim penyusun $A P B D$ juga menjadi penyebab anggaran disusun tidak tepat waktu.

Latar pendidikan sangat berpengaruh pada kinerja anggota DPRD Kabupaten Buru Selatan sangat berpengaruh negatif terhadap keterlambatan penyusunan anggaran. Baik Buruknya Kinerja anggota DPRD sangat berpengaruh pada tingkat pemahaman anggaran yang dicapai dari pelaksanaan program dan kebijaksanaan untuk mewujudkan visi, misi dan sasaran dari organisasi sektor publik. Artinya, semakin efektif dan efisien kinerja seseorang dalam mencapai pelaksanaan program dan kebijakan maka keterlambatan dalam penyusunan APBD dapat dihindarkan. Namun dalam prakteknya, masih banyak kendala yang muncul diantaranya, kurangnya informasi yang dimiliki pemerintah daerah untuk menentukan indikator kinerja yang diperlukan dalam APBD, adanya kesulitan untuk menterjemahkan indikator kinerja ke dalam elemen anggaran, serta adanya perubahan peraturan perundangan yang menjadi pedoman penyusunan APBD. Berbagai kendala tersebut yang diduga menjadi penyebab APBD Buru Selatan Tahun 2015 disusun tidak tepat waktu.

\section{b) Faktor Individual}

Latar belakang pengalaman yang dimiliki oleh anggota DPRD Kabupaten Buru Selatan masih sangat minim, yaitu dari keseluruhannya anggota DPRD yang terpilih pada pemilihan legislatif sebagian besar adalah wajah baru Artinya apabila ditinjau dari pola fikir yang dimiliki oleh anggota Legislasi sudah memiliki tahapan yang baik, karena dipengaruhi oleh faktor tingkat pengalaman yang dimiliki. Namun aktivitas pengalaman yang dimiliki oleh anggota Legislasi di 
Buru Selatan tidak keseluruhannya karena sebagaian besar berasal dari berbagai macam latar belakang yaitu dari pengusaha, wirausaha dan sebagai kecil dari wajah lama di legislatif. Dari data yang diperoleh bahwa 9 orang anggota DPRD Buru Selatan merupakan wajah lama yang berasal dari beberpa fraksi, dan sebagian besar anggota legislatif Buru Selatan merupakan wajah baru. Fakta ini tentunya membuat kemampuan dan keahlian personal anggota DPRD Buru Selatan dalam melaksanakan tugasnya, seperti menyusun dan merumuskan kebijakan daerah sangatlah menyulitkan.

Ketidakmampuan anggota Legislatif daerah dalam merumuskan dan menyusun kebijakan daerah memang mutlak faktor latar belakang pengalaman yang dimilikinya. Walaupun adan anggota Legislasi daerah yang sudah dua periode menjadi anggota dewan, tetapi akibat bukan keahliannya menyusun dan merumuskan kebijakan daerah tentunya tetap menjadi hambatan dalam melaksanakan tugasnya. Dampak dari rendahnya kemampuan dan keahlian yang dimiliki anggota DPRD Buru Selatan membuat banyak usulan kebijakan daerah itu berasal dari pemerintah daerah. Bahkan anggota Badan Legislasi terkadang hanya menerima usulan kemudian membahasnya untuk diusulkan menjadi sebuah kebijakan daerah. Padahal seharusnya anggota dewanlah yang menyusun dan merumuskan berdasarkan hasil pengamatan dan analisis yang dilakukan terhadap fakta, realita dan fenomena yang berkembang di lingkungan masyarakat. 


\section{5 c) Faktor Organisasi}

Anggota DPRD Kabupaten Buru Selatan pada pembahasan APBD Tahun 2015 dalam melaksanakan fungsi dan kewenangan sudah cukup baik karena anggota legislatif sudah mampu mengetahui tugas dan tanggungjawab dalam melaksanakan fungsi penganggaran. Namun kenyataan yang terjadi dilapangan sering terjadi tumpang tindih kewenangan dan beban kerja yang tidak mengikuti jadwal yang sudah ditetapkan oleh pihak eksekutif daerah. sehingga nampaknya pada proses penyelesaian perumusan dan penyusunan kebijakan daerah yang akan dibahas oleh masing-masing fraksi sering terlambat. Kemudian dalam pelaksanaan tugas anggota Dewan Perwakilan Rakyat Daerah (DPRD) buru Selatan sudah cukup mampu untuk saling bekerjasama dalam menyelesaikan tugas perumusan anggaran. Selain itu, pengalaman untuk menganalisis data dan informasi yang telah dikumpulkan selalu dijadikan bahan kajian dan analisis oleh setiap anggota legislatif dalam merumuskan kebijakian daerah. dari hasil pengamatan peneliti bahwa proses perumusan APBD Tahun 2015 yang dilakukan atas dasar kerjasama yang dikembangkan di internal institusi DPRD Buru Selatan untuk menjadikan bentuk kerja sama dan komitmen yang dimiliki anggota legislatif meujudja visi dan misi dalam mewujudkan perumusan kebijakan daerah yang komprehensif dan akuntabel.

Oleh karenanya lembaga DPRD Buru Selatan pada pembahasan APBD Tahun 2015 semestinya harus memainkian peran dengan baik apabila pimpinan dan anggota-anggotanya berada dalam aspek kualifikasi yang sempurna dalam arti mampu memahami hak, tugas 
dan kewenangannya dan mampu mengimplementasikan secara baik yaitu pengalaman politik selama menjabat maupun pengetahuan berorganisasi mampu mempengaruhi sikap dan tindakan dalam merumuskan proses penganggaran publik. Oleh sebab itu, pengetahuan anggota DPRD Buru Selatan sangat berpengaruh pada cara pandang terhadap mekanisme penyusunan anggaran mulai dari tahapan perencanaan sampai pada tahapan pertanggungjawaban serta pengetahuan anggota tentang peraturan yang mengatur pengelolan keuangan Anggaran Pendapatan Belanja Daerah (APBD) Tahun 2015.

Pengalaman anggota DPRD Buru Selatan tentang anggaran sangat erat dengan fungsi penganggaran dan fungsi pengawasan yang dimiliki oleh anggota dawan. Fungsi penganggaran yang melekat pada anggota DPRD untuk selalu ikut dalam proses pembahasan anggaran secara bersama-sama dengan eksekutif. Fungsi pengawasan DPRD memberikan kewenangan dalam pengawasan kinerja eksekutif dalam pembahasan APBD Buru Selatan. Maka dalam pelaksanaan fungsi penganggaran DPRD dituntut dapat bekerja secara efektif dalam melakukan pembahasan dan pelaksanaan anggaran. Maka untuk meningkatkan kapabilitas dalam pembahasan keuangan daerah, DPRD Buru Selatan harus menguasai keseluruhan proses penganggaran. Sehingga pengalaman dewan dalam pembahasan anggaran merupakan kemampuan anggota dewan yang diperoleh dari latar belakang pendidikan ataupun dari seminar tentang keuangan daerah yang selalu diikuti oleh anggaran dewan. 


\section{KESIMPULAN}

Berdasarkan pada hasil penelitian yang telah diuraikan di Pembahasan di atas dapat di uraikan bahwa pola interkasi eksekutif dan legislatif pada pembahasan Anggaran Pendapatan Belanja Daerah (APBD) Tahun 2015, mulai dari tahapan Perumusan KUA dan PPAS Serta Pembahasan RAPBD sampai pada tahapan pengesahan anggaran selalu diwarnai oleh beberapa fenomena interaksi antara eksekutif dan legislatif untuk melakukan fungsi kewenangan saling menguasai, mendominasi. Maka untuk menganalisis pola relasi eksekutif dan legislatif pada pembahasan APBD Kabupaten Buru Selatan Tahun 2015 maka akan diuraikian sebagai berikut:

1. Pada pembahasan APBD Kabupatenn Buru Selatan Tahun 2015 ditemukan tiga pola interaksi eksekutif dan legislatif yaitu akomondasi, dominasi, dan kompromi namun di antara ketiga pola interaksi dari keseluruhan pembahasan kebijakan anggaran ditemukan adanya proses pola yang lebih mendominasi. Pola interaksi eksekutif dan legislatif pada proses pembahasan di tingkat Panitia Anggaran dan tingkat komisi yang membidangi beberapa SKPD cenderung lebih dominatif pihak DPRD.

2. Pola interaksi Eksekutif dan Legislatif pada Pembahasan APBD Kabupaten Buru Selatan Tahun 2013 lebih di dominasi Pola Interaksi Decesional Yaitu Pola pertentangan yang berlangsung pada perumusan Kebijakan Umum Anggaran (KUA) dan Prioritas dan Platfom Anggaran Sementara (PPAS) sehingga mengakibatkan keterlmabatan penetapan APBD, pola interakasi kekuasaan yang terjadi tawar menawar (barganing) untuk 
melakukan pertukaran kepentingan legislatif kepada Eksekutif yang tidak diakomodir Pada Rencana Kerja Anggaran (RKA) di masing-masing SKPD.

3. Pola relasi Eksekutif dan Legislatif Pada pembahasan KUA dan PPAS di pembahasan APBD Tahun 2015 lebih di dominasi pola interaksi Anticipated Reaction yaitu Pemerintah Kabupaten Buru Selatan menerima kepentingan DPRD yang mejadi rekomendasi Reses untuk menjaga kestabilan pembahasan APBD Tahun 2015.

4. Pada pembahasan RKA Kabupaten Buru Selatan terjadi pola relasi Eksekutif dan Legislatif yang lebih didominasi oleh interaksi Non Decisional yaitu pihak legislatif menolak melakukan pembahasan KUA dan PPAS karena dari pihak eksekutif tidak menyerahkan dokumen Rencana Kerja Anggaran (RKA) dari masing-masing SKPD.

5. Pola interaksi eksekutif dan legislatif pada perumusan KUA dan PPAS ditemukan bahwa legitimasi pemerintah daerah sangat dominan dan interaksi kompromistik lebih banyak terjadi pada pembahasan akhir anggaran yang di bahasa oleh masing-masing SKPD di Kabupaten Buru Selatan. Sedangkan dominasi DPRD dalam kaitan ini lebih pada saat penetapan anggaran di mana kewenangan DPRD lebih kuat Karena mempunyai fungsi kewenangan pengawasan dan fungsi angggaran.

6. Pola relasi eksekutif dan legislatif pada proses pembahasan Kebijakan Umum Anggaran (KUA) serta Prioritas Platfon Anggaran Sementara (PPAS) pada Rancangan APBD Kabupaten Buru Selatan Tahun 2015 masih di dominasi oleh kepentingan 
politik sehingga berdampak pada berlarut-larutnya pembahasan anggaran sehingga mengakibatkan terlambatnya penetapan KUA, PPAS, serta APBD.

7. Pihak Pemerintah Kabupaten Buru Selatan (eksekutif) pada pembahasan KUA dan PPAS pada umumnya bersifat koersif di mana masing-masing SKPD memiliki kewenangan di fungsi penganggaran.Sementara, pola relasi perilaku ofensif lebih ditonjolkan ketika telah berdialog secara bersama dengan institusi DPRD (Legislatif) untuk membahas mulai pada penyusunan rancangan maupun perumusan APBD Kabupaten Buru Selatan.

8. Pola relasi Pemerintah Kabupaten (Eksekutif) dan DPRD (Legislatif) lebih dominan pada saat rapat pembahasan RAPBD pada masing-masing komisi yang membidangi beberapa SKPD terkait, maka posisi DPRD secara umum menunjukan perilaku yang dominani pembahasan anggaran. Pola relasi DPRD cenderung melakukan negosiasi, lobby kepentingan proyek pada Sub program yang terdapat pada tiap SKPD. Maka di setiap proses pembahasan anggaran yang melibatkan DPRD selalu diwarnai oleh negosiasi anggaran publik.

9. Pola Relasi eksekutif dan legislatif pada pembahasan APBD Tahun 2015 sangat berpengaruh pada Personal Bachground, political Bachground anggota DPRD dalam melakukan pengelolaan anggaran Kabupaten Buru Selatan, pola interakasi berpengaruh baik secara bersama-sama maupun parsial terhadapan kemampuan dan pemahaman dalam pelaksanaan pembahasan anggaran. 


\section{DAFTAR PUSTAKA}

[1] Amal, Ichlasul dan Winarno, Budi 2007, Metodologi Ilmu Politik. Pusat studi IImu Sosial UGM.

[2] Helmke, Gretchen dan Steven, Levitsky "Informal Institution and Comparative Politic: A Research Agenda Working Paper\#307.203".

[3] Madani, Muhlis. 2011. Dimensi Interaksi Aktor Dalam Proses Kebijakan Publik. Graha Ilmu. Yogyakarta.

[4] Setiabudi, Elly M dan Kolip, Usman 2011. Pengatar Sosiologi "Pemahaman Fakta dan Gejala Permasalahan Sosial: teori dan Aplikasi, dan Pemecahannya". Jakarta. Penerbit Perpustakaan Nasional: Katalog Dalam Terbitan (KDT)

[5] Seidman, Ann, Seidman, Robert B. and Abeyserkeve, Nalin. 2001. Penyusunan Rancangan Undang-Undang Dalam Perubahan Masyarakat Yang Demokratis, Sebuah Panduan Untuk Pembuat Rancangan Undang-Undang. Terjemahan oleh Usfunan, Johanes et.al. Proyek ELIPS, Jakarta.

[6] Soekanto, Soejono 2006, Sosiologi Suatu Pengantar, Jakarta: Rajwali Press.

[7] Abdullah, S. 2012. Perilaku Oportunistik Legislatif dan Faktor-Faktor Yang Mempengaruhinya: Bukti Empiris dari Penganggaran Pemerintah Daerah di Indonesia. Ringkasan Disertasi. Universitas Gajah Mada.

[8] Abdullah, S. dan Asmara, J.A. 2006. Perilaku Oportunistik Legislatif Dalam Penganggaran Daerah: Bukti Empiris atas Aplikasi Agency Theory di Sektor Publik. Makalah Simposium Nasional Akuntansi 9. Padang: 23-26 Agustus 2006.

[9] Pariury, Gabrielle Issabelle O., and Priyo Hari Adi. "Political Interest Legislatif Dalam Pengalokasian Anggaran Daerah Pada Sektor Pekerjaan Umum." 